\title{
Election and Development in Federal Nepal: Perspective of APF in Election Security
}

\author{
Bharat Khaniya \\ Deputy Superintendent of APF, Nepal \\ Student Officer, $3^{\text {rd }}$ APF Command and Staff Course \\ Email: khaniya_bp@yahoo.com \\ Arun Kumar Sharma \\ Deputy Superintendent of APF, Nepal \\ Student Officer, $3^{\text {rd }}$ APF Command and Staff Course \\ Email: arunapf@gmail.com
}

\begin{abstract}
Free and fair elections are the elements that contribute in strengthening the democracy. They are more important for the fragile democracies like Nepal. The new constitution promulgated in 2015 by Constituent Assembly led the country to federal state. Elections of all three tiers of government were to be held within two years from the date of promulgation. The constitution granted a number of tasks to be performed by local bodies for the development of the country. Elections and development are interrelated and connected. Elections elect candidates and those candidates are the vehicle of development. But the first year passed by without doing much and later government had to execute the task within the period of eight months. Local elections were planned and held in three phases due to security reason, whereas, provincial and federal elections were completed in two phases. All security forces mobilized in duty performed their duty well and elections went on peacefully except some petty incident in some parts of the country.

This article is centered on the security provision of election and a long-term security plan. It needs to be prioritized by the government, as the security situation deteriorates further each day. Antielection elements, agitating groups attempting to achieve their rights, lack of law and order, and banditry are just some of the security challenges Nepal is currently facing, and affects the ability to hold free and fair elections. Consequently, security is integral and inseparable part of an election and electoral process. The study concluded that the security agencies were proactive, capable of providing security to the political leaders, candidates and voters perform their functions effectively and peacefully during legislative elections 2017.
\end{abstract}

Key Words: Democracy, election security, local body, development, security management

\section{Introduction}

Nepal's political parties are the drivers of the change. They are capable to resolve grievances related to class, caste, and gender, as well as to other political, economic, social and cultural challenges faced by Nepal (Dahal, 2014). In reality, the political parties are entangled in their own interests and demands instead of the peace process and peace building for the nation and its people.

Successful "peace building" in war-torn countries like Nepal is said to involve a triple transition: a security transition from war to peace; a political transition from authoritarianism (or totalitarianism) to a more participatory form of government; and a socio-economic transition, including the rebuilding of economic capacities (Thapa, 2008; Zeeuw, 2001). Peace is not just the absence of war, but also economic prosperity, social harmony, unity and solidarity among the multi-ethnic Nepali people. There should be a purposeful development to create democratic institutions for more open, participatory and successful society (Thapa, 2008). In the aftermath of the 2007 People's Movement 
Khaniya \& Sharma: Election and Development in...| 38

- II, the 240 years of monarchy was abolished by $5^{\text {th }}$ Amendment of the Interim Constitution of Nepal, 2063. The Amendment was first document to mention Nepal officially as the Federal Democratic Republic of Nepal. It envisioned federalism as a prominent feature for a new Nepal.

As per the new constitution, $2072 \mathrm{BS}$, elections in all three level of governance were supposed to be held within the next two years (Ethirajan, 2017). The first election, local level assembly, began in Baisakh - the first month of the year, 2074. It was however held in three phases in Baisakh, Asar and Asoj, led to a foundation for the election to the House of Representatives and the Provincial Assemblies, which were held in the month of Mangsir. So in a way, all three elections were held in a span of eight months. The local level elections had already been held in the country but the local election of this time is different in nature whereas the provincial and federal level elections have been held for the first time in Nepal.

Local level election is the democratic course of action for decentralization and has become an increasingly widespread and significant dimension of political and administrative reform in many developing countries since the late 1980s. This process is supported by a various actors like; international development agencies to national governments to non-governmental and grassroots organizations. Decentralization is presumed to have a number of benefits, including positive outcomes in both democratic and developmental terms. It is assumed that democracy will be deepened by the extension of political representation to the local level, with democratic processes strengthened through enhanced political participation by local civil society actors. It is assumed that benefits in socio-economic development will mount up through local government being more responsive and more accountable to citizens' needs and desires. Representativeness and participatory are two benefits of local- level government. These two benefits are interlinked which lead to effective development planning processes and the delivery of public services that are relevant to the local context.

The constitution of Nepal 2072 has introduced a three-tier governance system; national, provincials and local levels. A Local Body Restructuring Commission was established as required by the constitution under the chairmanship of Balananda Paudel. The commission proposed 719 local structures which were revised to 753 by the government. But the new local levels were formed by changing the existing cities and village development council and came into existence on 10 March 2017. The electoral system has provisioned that Local levels will have a Mayor/ Chairman and a Deputy Mayor/ chairman. Local levels are further subdivided into wards which will have a ward chairman and 4 additional members. Out of the 4 members two must be female. All are elected for fixed term of five years. The election is First Past The Post (FPTP), direct in nature, and with the one getting the most ballots is declared the winner. There are four types of local governance; Metropolitan City, Sub Metropolitan City, Municipality and Rural Municipality. Total Mayor/ Chairperson 753, Deputy Mayor/ chairperson 753, ward chairperson 6,742 and ward member 26,790 are elected from local body election (Kathmandupost, 2017).

Regarding the election security threats; unhealthy competition among the political parties, antielection elements, underground armed groups, separatist organizations, ethnic groups, regional groups, secessionist groups, gangsters and small arms and explosion carriers are the major challenges of election security. The first phase of election was largely peaceful but there were random instances of violence. A CPN-UML activist was killed in Gaurisankar Village Development Committee (VDC), Dolakha on the eve of election. Another person was killed in Namobuddha municipality; Kavre on the day of election, the incident is still under investigation. One person died after security personnel opened fire during a clash between the cadres of Nepali Congress and CPN-UML in 


\section{9 | Journal of APF Command and Staff College}

Melung VDC of Dolakha district on Election Day. A candidate from RastriyaPrajantantra Party died in Naraharinath VDC, Kalikot after police opened fire when cadres of NetraBikram Chand led CPN tried to capture the ballot boxes. A reelection took place in one ward of Bharatpur Metropolitan after a CPN-Maoist Centre vote count representative tore 90 ballot papers when the count was in progress. In the second phase, an UML cadre died after being hit by a stone in his testicles during a clash with Nepali Congress cadres at Chededaha Village council Bajura. A cadre of NetraBikram Chand-led CPN Maoist died in Dhangadi, Kailali after a bomb carried by him exploded prematurely on June 26, 2017 (APF, 2017).

The rampant issues bulging out as a handicap to the election process are; Dominance of money power and Muscle power, Criminalization of politics, Financing of election exceeding the legal limit, Booth capturing, Intimidation of voters, Buying Voters, Tampered electoral rolls, Large-scale rigging of elections, Abuse of religion and caste in the enlistment of voters, etc.

\section{Developmental Issues}

Development as a concept is a victim of definitional pluralism. It is a difficult word to define. Development is usually taken to involve not only economic growth, but also some notion of equitable distribution, provision of health care, education, housing and other essential services all with a view to improving the individual and collective quality of life in a sustainable way so that today's consumption does not imperil the future. It is a process of societal advancement, where improvement in the wellbeing of people is generated through strong partnerships between all sectors, corporate bodies and other groups in the society. It is reasonable to know that development is not only an economic exercise, but also involves both socio-economic and political issues and pervades all aspects of societal life. National development can be described as the overall development or a collective socio-economic, political as well as religious advancement of a country or nation. This is best achieved through development planning, which can be described as the country's collection of strategies mapped out by the government.

The challenges of national development of Nepal are mixed of incompatible development strategies and unfaithful implementations. Inadequate resources, lack of good governance, lack of visionary and national leadership, political and socioeconomic instability, lack of investment security, corruption and indiscipline, complex geography, high degree of dependency, small diplomacy, laxness national character, lack of knowledge and skills in people, lack of people's participation in decision-making, lack of ownership in people and deficiency of being competent culture are considered as the major challenges of development process. There is some instance of praising development and well beings of people in the world; the visionary leadership has changed the country.

The prospect of national development is initiated, as a bottom- up model, with the local level election and formed up the local body. Recently, people have elected around thirty five thousands representatives for local body who will be directly participating in decision-making process. People's participation in decision-making may play significant role on local development through political stability, creation of investment environment and rationale in using available resources. Local level is foundation of democratic society which kicks off the social mobilization for progress, good governance and the prospects of national development.

Local body is the foundation of democracy, people's participation in decision- making procedures, ownership in state matters and sustainable development. Elections are a procedural or institutional demonstration of democratic values and practice. It is also the means of political stability, social 
Khaniya \& Sharma: Election and Development in...|40

mobilization, justice, change, public service improvement, security, rule of law, development and democratic policy towards the appearance of freedom of choice and freedom of political thought. When national identity, development and justice issues are part of electoral platforms and debated in seriousness, elections come to serve three purposes. They provide an opportunity for learning from multiple perspectives. It is commonly recognized today that elections are not a source of insecurity, challenges and conflict. On the contrary, when they are well managed, they are expected to help prevent conflicts, prospect of sustainable development, arbitrate between the various concepts of managing state affairs and can even serve as a safety valve for any representative democracy worth the name. As we know that local level is the base of democracy, similarly it is also the backbone of sustainable development and wellbeing of people.

Concept of federalism is old in the context of world but it is new in Nepal. This has been adopted as democratic norms to develop the country more. Nepal is in practice of federal system and just completed Local level, Federal and Provincial election. Legislative elections were held in two phases on 26 November and 7 December 2017. The election in first phase was held for 37 constituencies of the House of Representatives and 74 constituencies of the provincial assemblies in the provinces. The second phase took place on December 7 in 45 districts of the Tarai and Hills. A total of 128 seats for the House of Representatives and 256 of the provincial assembly candidates were elected in the second phase by FPTP. Another 110 members in House of Representatives and 220 members in Provincial Assemblies were also elected by Proportional Representations (PR) (Clarke, 2017).

The nation's 32 mountainous regions were among the first to cast their votes. Approximately three million eligible voters were expected to participate in the first round of elections; however, the actual turnout was just over 65 percent. Except for some minor complaints from a few places, polling in all areas went smooth and peaceful.

\section{Security Challenges}

The political parties were expected to exercise professional conduct and ethics. It was equally important that security forces did not use excessive forces while tackling with political cadres. The anti-election groups had prepared since long time targeting the elections with highly equipped explosives. Nepal Communist Party (NCP) took responsibility for some of the explosion incidents whereas few were not identified. Bombs were detonated targeting even candidates. There had been over a hundred minor and major explosions in the run of the elections targeting electoral assemblies and leader. A temporary police was killed in Dang from an explosion at an event attended by the Prime Minister. Nepali Congress candidate Narayan Karki was injured in an targeted explosion to his vehicle in Udayapur while 11 people including former Health Minister GaganThapa were injured from an explosion in Kathmandu (Rastriya Samachar Samiti, 2017).

During the silence period, IEDs were found and defused in several places. The series of explosion took place throughout the country and the government was criticized for lack of proper security management and a poor security system. Violence during the campaign is usually aimed at changing electoral outcomes, often by targeting candidates and supporters. The causes of electoral violence were seen as a sub-set of political violence with a coercive and deliberate strategy used by groups or political parties to advance their interest in the face of an uncertain election outcome.

\section{Security Management}

More than 90 percent security personnel have been deployed for the security of candidates, voters, polling officers and polling centers. Security agencies assured that there was no any confusion on 


\section{1 | Journal of APF Command and Staff College}

security threat and well prepared to cope with the situation, so that, voters could exercise their franchise in free and fearless manner.

A central security command had been formed to mobilize security forces at the regional and local level. Around 65,000 Nepal Police, 28668 Armed Police Force, 98,000 temporary cops and 34,000 Nepal Army personnel were mobilized to provide security for the second phase of polls. Besides, officials from the National Investigation Department were also on the ground (Gautam, 2017). The integrated security arrangement of the government specified the role and responsibilities of security apparatus. Nepal Police was tasked to secure polling stations and centers while the APF was tasked for second layer security whereas outer layer security responsibility was given to Nepal Army. Apart from this, mobile vans of Nepal Police and the APF constantly patrolled polling centers and stations.

Ministry of Home Affairs (MoHA) had assured security responses within 10 to 30 minutes in case of any threat to polling centers or voters during the first phase parliamentary and provincial assembly elections. The government had arranged three layers of security comprising a joint force of Nepal Police and temporary police personnel, Armed Police Force and the Nepal Army. There was an arrangement of air and land patrolling for quick security response, in view of the geography of the country. The government had hired helicopters from private companies to cover the remote areas. The Home Ministry had also arranged enough reserve forces in addition to the three-layer security (Karki, 2017).

\section{Mobilization of APF and Challenges}

Armed Police Force was mobilized in election security as per overall election security plan and was mandated to perform its duties being in the second layer. Numbers of APF personnel mobilized in elections were deployed as per the severity of security situation of election centers. The election centers were categorized as most sensitive, sensitive and normal. In the first round of election a total of 14682 APF personnel were deployed in 32 mountainous districts of the country. In second round of elections 28668 APF personnel were mobilized for election security. Altogether the number was 43350 (APF, Operation Department, 2017).

Although the number of APF deployed seems big but given the open international border, political and security situation and the political culture it is not so big. Besides, APF was also mandated to provide security to candidates, political rallies, election offices and security of voters. Geographical condition, condition of roads and vehicles were the main challenges in providing security. A total of 88 parties were granted ballot access under the proportional system and having 49 parties submitted list of proportional candidates. The number of candidates was so big and each of them demanding security in their political campaign was another challenge. Inability to provide security to them would result in questioning the capacity of security apparatus.

The role of APF was even more challenging because Nepal Police, an organization having more than 73000 personnel was only limited in securing the election booths. Nepal army was for security of outer ring and was not involved in day- to- day problems and only monitored the situation. Last 3 days prior to election, also called the silence period, are considered as most sensible period and security of that period is very crucial to security organizations. Many incidents of confrontation and unethical behavior happened during that period and APF had to respond all these incidents without having food and sleep in time. 


\section{Way Forward}

Silence periods have remained crucial throughout election as it results in the formation of new government and many more in our context. All the parties and cadres give more priority and apply their full effort to win election. Use of power, money and muscle are considered as vital elements to win. Porous border, criminal activities, prevalent political culture and mentality of candidates are also influential. We need a system in place to monitor, prevent, mitigate and manage electoral violence throughout the electoral cycle. The government should critically analyze the current security systems, while political parties should critically analyze on their conducts and reform themselves accordingly. The government must protect the candidates, and the rights of citizens to participate in the electoral process without fear of violence.

So, country like Nepal should be able to provide sufficient security during election and that is only possible by having the adequate size of security forces that can act independently; and equipping them adequately. Politicians also have to change the mentality of not providing anything during peace and general situation and looking for security for everyone during election period. Policy makers should understand that security forces cannot be prepared within a week or months. It takes a long period, investment and preparation to have effective security force and it is time to think and prepare for next election.

\section{Conclusion}

Nepal needs to achieve sound economic status to address the requirement of post conflict scenario. There is a long way to maintain positive peace even the conflict has ended. Despite of successful completion of peace process, the nation's political system has failed to build sustainable peace due to lack of political culture. The numerous political parties urge a constant struggle for power to fulfil their own wishes and interests. The political parties are the driving force in Nepal for political and economic stability so they could and should solve the economic and social problem and build prosperous Nepal. Federal, provincial and local level elections are conducted successfully and peacefully. People had already given the consent and mandate to practice the new political journey for the peace, development and prosperity.

\section{References}

APF, (2017), Armed Police Force Nepal Operation department's Local level election report 2074, Kathmandu: APF HQs.

APF, Operation Department. (n.d.). Sasastra Prahari Balko Parichalan. APF, Nepal, HQ.

Clarke, M. (2017, December 8). Nepal's Parliamentary and Provincial Elections Seen as Success. The Diplomat.

Dahal, D. R. (2014). Devraj Dahal's keynote address presented at a political dialogue titled Institutionalization of Inner-Party Democracy in Nepal jointly organized by CelCar and FES on 24 December 2014.

Ethirajan, A. (2017, November 26). Nepal election: First poll since civil war ended. Bbcnews.Com.

Gautam, M. (2017, December 7). Over 200,000 security forces for today's polls. Kathmandu post: http://kathmandupost.ekantipur.com/news/2017-12-07/over-200000-security-forces-fortodays-polls.html 
43 | Journal of APF Command and Staff College

Karki, D. P. (2017, December 5). Security threat for election. My Republica. Retrieved from http://election.nagariknews.com/news/32076/en

Kathmandupost, (2017), 2074, a year of elections, source: Rastriya Samachar Samiti, Kathmandu, retrieved on 15th February 2017 http://kathmandupost.ekantipur.com/printedition/news/201711-26/2074-a-year-of-elections.html.

Rastriya Samachar Samiti. (2017, December 1). Security strategy to be reformed for upcoming elections. The Himalayan Times. Retrieved from https://thehimalayantimes.com/nepal/security-strategy-reformed-upcoming-elections/

Thapa, (2008), The paper 'Role of civil society and political party in current nation/state building process in Nepal' presented on seminar titled 'New Dynamics of development: Challenges and prospects' organized by Centre for economic and technical studies (CETS) and FriedrichEbert-Stiftung (FES), Kathmandu on 12 \& 13 Nov 2008. 